\title{
ARTIKEL AUDIT SISTEM INFORMASI SUMBER DAYA MANUSIA PADA TRAINING CENTER DI JAKARTA
}

\author{
Putra Rahmadi \\ 155100058 \\ Universitas Mitra Indonesia, Sistem Informasi \\ Putrarahmadi.students@umitra.ac.id
}

\begin{abstract}
ABSTRAK
Smartlearning merupakan jenis perusahaan training center di bidang information Technology (IT) bagi perusahaan swasta atau institusi pemerintah, yang di prioritaskan pada pengembangan dan keahlian karyawann untuk berbagai keperluan yang spesifik dengan materi yang sesuai dengan kebutuhan, waktu dan tempat yang disesuikan dgn keinginan customer. Dengan meningkatnya kuantitas pelaksanaan training tentu saja harus diseimbangkan dengan tingginya kualitas sumber daya manusia yang ada. Untuk melihat semuanya itu maka perlu dilakukanlah suatu kontrol dan audit terhadap sistem tersebut, agar dapat dilihat keefektifan sistem tersebut dan untuk meminimalkan resiko atau pengeluaran serta memaksimalkan keuntungan yang diperoleh oleh perusahaan dengan berbagai metode kontrol. Teknik kontrol dapat diterapkan dan diselaraskan dengan tujuan TI serta tujuan perusahaan diperlukan suatu pengukuran tingkat keselarasan antara tujuan perusahaan dengan tujuan TI.
\end{abstract}

Kata Kunci: Training Center, Sumber Daya Manusia 


\section{A. PENDAHULUAN}

a. Latar Belakang

Smartlearning memberikan program sertifikasi untuk kalangan individu maupun perusahaan yang berkeinginan untuk mencari atau melengkapi sertifikasi IT berskala international. Program sertifikasi ini terdiri dari training persiapan ujian sertifikasi dan ujian sertifikasi.

Saat ini banyak bermunculan jenis usaha yang sama, hal ini tentunya memperketat persaingan, baik dari sisi kualitas materi training sampai kepada kualitas pelayanan terhadap konsumen. Untuk Memastikan kualitas dan layanan yang diberikan oleh Smartlearing dapat terarah dan selaras dengan tujuan bisnis perusahaan, untuk pemberian materi training dipilih Instruktur dari para profesional, praktisi dan akademisi yang memiliki sertifikasi industri dan yang memiliki pengalaman riil dalam mengembangkan project-project teknologi informasi sesuai dengan core competence masing-masing.

Saat ini ada semacam kecenderungan yang meningkat (growing trend) terhadap pelaksanaan training dan juga terdapat peningkatan kebutuhan (growing demand) dari pelanggan Perusahaan training center tersebut.

\section{b. PERUMUSAN MASALAH}

Perumusan Masalah yang akan dianalisis dan diaudit pada bagian sumber daya manusia (SDM) di Smartlearning yaitu

i. Apakah proses bisnis perusahaan, khusus nya di SDM, telah mendukung tujuan bisnis perusahaan?

ii. Apa saja masalah yang dihadapi perusahaan dalam mengimplementasikan sistem SDM yang sudah ada?

\section{B. TINJAUAN PUSTAKA}

a. Audit Sistem Informasi

Audit Teknologi informasi pada hakekatnya merupakan salah satu dari bentuk audit operasional, tetapi kini audit teknologi informasi sudah dikenal sebagai satu satuan jenis audit tersendiri yang tujuan utamanya lebih untuk meningkatkan tata kelola IT. Sebagai suatu audit operasional terhadap manajemen sumber daya informasi, yaitu efektivitas, efisiensi, dan ekonomis tidaknya unit fungsional sistem informasi pada suatu organisasi. Dengan diperkenalkan COBIT, kini tujuan audit bukan hanya terbatas pada konsep klasik saja, melainkan kini menjadi: efektivitas, efisiensi, kerahasiaan, keterpaduan, ketersediaan, kepatuhan pada kebijakan/aturan dan keandalan sistem informasi. Dalam pelaksanaannya, jenis audit ini berkembang dalam beberapa variannya:

i. Pemeriksaaan operasional (operational audit) terhadap pengelolaan system informasinya, atau lebih tepatnya/tegasnya terhadap tata- kelola teknologi informasi (IT governance),

ii. General information review, audit terhadap sistem informasi secara umum pada suatu organisasi tertentu,

iii. Audit terhadap aplikasi tertentu yang sedang dikembangkan (quality assurance pada tahap system development).

\section{b. Sumber Daya Manusia}

Sonny Sumarsono (2003, h 4), Sumber Daya Manusia atau human recources mengandung dua pengertian. Pertama, adalah usaha kerja atau jasa yang dapat diberikan dalam proses produksi. Dalam hal lain SDM mencerminkan kualitas usaha yang diberikan oleh seseorang dalam waktu tertentu untuk menghasilkan barang dan jasa. Pengertian kedua, SDM menyangkut 
manusia yang mampu bekerja untuk memberikan jasa atau usaha kerja tersebut. Mampu bekerja berarti mampu melakukan kegiatan yang mempunyai kegiatan ekonomis, yaitu bahwa kegiatan tersebut menghasilkan barang atau jasa untuk memenuhi kebutuhan atau masyarakat.

\section{STUDI KASUS}

training canter ini yang di prioritaskan pada pengembangan dan keahlian karyawann untuk berbagai keperluan yang spesifik.

\section{DISKUSI}

Saya tidak berdikusi dengan teman.

\section{E. KESIMPULAN}

i. Sistem sumber daya manusia di training center yang saat ini diimplementasik an sudah sesuai dan mendukung tujuan bisnis perusahaan tersebut.

\section{F. REFERENSI}

[1] PUTRA, Arie Setya; FEBRIANI, Ochi Marshella. Knowledge Management Online Application in PDAM Lampung Province. In: Prosiding International conference on Information Technology and Business (ICITB). 2018. P. 181-187.

[2] FEBRIANI, Ochi Marshella; PUTRA, Arie Setya. Sistem Informasi Monitoring Inventori Barang Pada Balai Riset Standardisasi Industri Bandar Lampung. Jurnal Informatika, 2014, 13.1: 90-98

[3] Putra, A. S. (2018, July 9). 2018 Artikel Struktur Data, Audit dan Jaringan Komputer. Retrieved from osf.io/3uq8w

[4]

http://publikasi.mercubuana.ac.id/files/ journals/19/articles/1205/submission/c opyedit/1205-2706-1-CE.pdf 